\title{
Risk Attitude, Insurance Patronage and SMEs Performance: Empirical Evidence from Lagos, Nigeria
}

\author{
Sunday Stephen AJEMUNIGBOHUN ${ }^{\star}$, Ogorchukwu Augustine ISIMOYA ${ }^{\star}$, \\ Ayobami Folarin ELEGUNDE ${ }^{\star \star \star}$
}

\begin{tabular}{l}
\hline \multicolumn{1}{c}{ A R T I C L E I N F O } \\
\hline Article history: \\
Accepted June 2020 \\
Available online August 2020 \\
\hline JEL Classification \\
G22, M13, M21 \\
Keywords: \\
Risk attitude, Insurance patronage, \\
SMEs performance, Risk \\
management communication, \\
Nigeria
\end{tabular}

\section{Introduction}

Several studies with divergent opinions had shown that enterprises of either small or medium capacities are instrumental to steady growth of any country of the world (Abotsi, Dake, \& Agyepong, 2014; Garg \& Makukule, 2015; Dougherty-Choux, Terpstra, Kammila, \& Kurukulasuriya, 2015). Recent researches (such as Ajemunigbohun \& Adeoye, 2018; Chartterjee \& Wehrhahn, 2017; Ledwin \& Watson, 2019) have further proven that small and medium enterprises are accelerated wheel driving towards attaining the yearning objectives of many developing nations in respect of fund mobilisation, employment generation, economic improvement, labour intensiveness, revenue generation, technology advancement and the likes. Estimations from past studies (such as Ayyagari, Demirguc-Kunt, \& Maksimovic, 2011; Chodokufa, 2009; Ruchkina, Melnichuk, Frumina, \& Mentel, 2017) adjudged to the fact that not less than 95 percent of enterprises were SMEs which accounted for 60 percent private sector job opportunities. They reiterated the contributory quota of SMEs in terms of businesses and job opportunities within African to stand approximately around 90 percent and 50 percent respectively.

However, SMEs is often being perceived as the moving vehicle to tighten the space between the upper class and the downtrodden. Major concerns had ensued from government severally to facilitating SMEs vigorously to catch up with sustainable development goals at all levels. Even at this, a whole lot of SMEs operators in many countries especially developing countries like Nigeria and any others are faced with political, economic and financial risks which invariably created numerous devastating situations meddling around their operational activities. According to Ajemunigbohun and Adeoye (2018), SMEs were suggested to be faced with inoperative risk management template, poor risk management education and poor risk communication plans. Stulz (2008) as cited in Fadun (2013) noted that failure in SMEs risk management frameworks crop up as a consequent upon mismeasurement of identified risks, failure in risk communication, failure in risk monitoring, failure in risk assessment and failure in proper use of risk metrics. Earlier work by the Insurance Information Institute (2005) proposed that most SMEs operators are faced with disaster risk and thus lack disaster recovery strategies, which incapacitate, many at times, their operational and financial tenacities to survive. To corroborate this, Mambula (2002) earlier averred that the incapacity of SMEs'

\begin{abstract}
This paper has been to able to ascertain the significant influence of risk attitude on SMEs market share vis-à-vis a relationship between insurance patronage and their financial
earnings in the metropolis of Lagos. Descriptive survey design was adopted cum singlestage cluster sampling technique. 256 sample representation produced robust responses but low relationship between insurance patronage and financial earnings of SMEs in Lagos financial based resources to help incorporate, implement and fund insurance educati
curriculum that will facilitate progress, steady growth and development of the youths.
\end{abstract}

(C) 2020 EAI. All rights reserved. 
operators to carefully identify and assess various risks they encountered will disrupt their strength to survive.

The word 'risk' is a home-based concept that every mankind has been living with. It is evident because it is central to human and business existence and survival. It pervades every facet of human life either in the area of business or for non-business purposes. According to Redja and McNamara (2014), risk is at the centre of insurance and is inseparable from life. Unfortunately, insurance sectors in most developing countries are characterised by ineffective regulatory plans, undue perception, low technological drive, and inappropriate asset handling capacities (Ahmed \& Zalina, 2008 as cited in Ajemunigbohun and Adeoye, 2018). Other studies explicitly encapsulated the obnoxious nature of insurance industry in Nigeria in terms of distrust (Ojikutu, Yusuf, \& Obalola, 2018); low insurance popularity and patronage (Badru, Yusuf, \& Isola, 2013; Nwankwo \& Ajemunigbohun, 2013; Okechukwu, 2016); poor risk attitude (Adamu, 2018; Ajemunigbohun \& Oreshile, 2014); inefficient claims settlement (Olowokudejo \& Ajemunigbohun, 2018); to mention few. Quite a number of studies had advocated the uptake of insurance in the continent of Africa in a number of countries such as Rwanda, South Africa, Ghana, Kenya, Nigeria, Ethiopia, to mention a few (Charles \& Kioku, 2016; Chitiyo, 2017; Fofie, 2016; Langat, Naibei \& Getare, 2017; Owolabi \& Agboola, 2018; Sulaiman, Migiro, \& Yeshihareg, 2015); yet many research findings had not been related to patronage on the side of small and medium-sized enterprises. Nigeria, as a case study, is still on the quest for sizeable studies to be conducted in this regard.

The overall objective of this study is to examine the relationship between risk attitude, insurance patronage and SMEs performance in the metropolis of Lagos. The specific objectives therefore are investigating the significant influence of SMEs operators' risk attitudes on their market share in the Lagos metropolis; and thus, ascertaining the significant relationship between SMEs operators' insurance patronage and their financial earnings in the Lagos metropolis. This paper further attempts to provide answers to the following research questions: what significant influence do SMEs operators' risk attitudes have on their market share in the Lagos metropolis? and what is the significant relationship between SMEs operators' insurance patronage and their financial earnings in the Lagos metropolis? the authors then make the following hypothetical statements for the study:

H: $\quad$ SMEs operators' risk attitudes have no significant influence on their market share in the Lagos metropolis.

H2: $\quad$ There is no significant relationship between insurance patronage and financial earnings among SMEs operators in Lagos metropolis

\section{Literature review}

Neneh and Van Zyl (212) had accentuated that the sustenance of business practices is predicated upon the discharge of quality managerial tenets and methodologies in handling businesses which will gradually improve business performance especially in the application of business excellence in major facets of an enterprise. However, this business excellence cannot be easily achieved by business operators or owners without encountering some sorts of risks in the course of the business. Therefore, business risk should be anticipated by owners or operators of businesses in the attainment of desired successes. To this end, Dafikpaku (2011) defined business risk as the entirety of all risks a business organisation faces in the course of conducting its business activities. Earlier submission by Olsson (2002) gave it as the risk of failing to achieve required business goal as a consequence of inappropriate plans, restricted resources or economic /competing situational changes. It is thus described as the extent to which the consequential effect from organisation's corporate tactics different from those stipulated in its organisational overall objectives (Dickinson, 2011 as cited in Obalola \& Ajemunigbohun, 2017). Importantly, no matter the quantum of risks a business enterprise is faced with, it is incumbent on its owners or operators to facilitate processes that would assist in proper and effectual management of every facet of the risk situations.

Business risk management, then, is defined as the financial and operational handling of risk in tandem with the maximisation of effective cost within the restrictions of the firms' tolerance for risk occurrence (Kleffner, Lee, \& McGannon, 2003). Gatzert and Martin (2013) gave it as the combination of all risks across conglomerate firm, which takes cognisance of interrelationships between risks, that permits for an improved evaluation of the organisation's risk situation and thereafter enhance the output process in reference with operational and strategic developments. A submission by Yazid, Razadi and Hussin (2012) affirmed that the integration and coordination of all sorts of risks across the totality of the firm could efficaciously be exerted to curtail such organisation's operational risk situations. A submission by Labodova (2004) pinpointed at business risk management as relevant process that SMEs can employ to enhance their opportunity of improved and desired longevity. Earlier suggestion by Fatemi and Glaum (2000) declared that the basic objectives of business risk management is to guarantee the survival of a firm. Turpin (2002) submitted that most SMEs wield no impeccable risk management plan to deploying risk management skills to employees. Janney and Dess (2006) opined that SMEs are not conversant with the adoption of positive strategy towards risk management due to a number of challenges such as insufficient infrastructure, shortage in financial and intellectual resources, restricted managerial and technical know-how, weak information 
network and slack investment in research. According to an earlier submission by Hill (2000), managing risk is identified as an integral segment of small and medium scale enterprises. Also, Ow (2007), proposed that risk management practices should be made simplified and incorporated in the operational plan and firm's culture of SMEs in order for business performance improvement and right attitude towards risks.

Saeidi, Sofian, Abdul Rasid, Saeidi, and Saeidi (2013) stipulated that trust, built overtime in the right attitude towards risk, serves as mechanism driving impressive risk management and that business risk management should be well enhanced by designing, improving and maintaining efficient organisational risk tools. Therefore, SMEs' capacities building toward deploying necessary risk management tools is encapsulated in the right-thinking risk attitude displayed genuinely to attaining the desired organisational objectives. Risk attitude, therefore, is said to be an individual's orientation toward taking or avoiding risk when deciding how to proceed in situations with uncertain outcome (Rozen, Tsai \& Downs, 2005 as cited in Glanz, Greeke, LaRussa, Stuart, Rintell, Chitnis, \& Healy, 2016). While earlier submission by Wu and Chan (2007) depicted risk attitude as a stable personality characteristic that is embedded in an individual; Hillson and Murray-Webster (2007) as cited in Fadun (2013) affirmed that people adopt risk attitude which affect every facet of risk process, even if they are oblivious of it. They further depicted risk attitude as a source of significant bias on decision making and the effectiveness of risk management process. Many studies had shown that the level of risk attitude exhibited by an individual or business enterprise is a function of the patronage for insurance products (Adeleke, Olowokudejo, \& Ajemunigbohun, 2016; Aduloju, Isimoya \& Ajemunigbohun, 2018; Nyce, 2007). Insurance, as a risk transfer system, is being defined as an equitable transfer of the risk of a loss, from one entity to another, in exchange of a premium (Collier, 2009). It has thus been delineated as a periodic payment for specific types of losses which may occur in the future (Eregue, 2017). From another perspective, it is seen as the pooling of fortuitous losses by transfer of such risk to insurers, who agree to indemnify insureds for such losses, to provide other financial benefits in their happenings, or to render services associated with the risk (Redja \& McNamara, 2014). Thus, Vaughan and Vaughan (2014) defined insurance as an economic instrument whereby the individual substitutes a small certain cost (the premium) for a ginormous uncertain financial loss (the contingency insured against). An earlier submission by Outreville (1998) gave it as technique for financing risks by combining a sufficient number of loss exposure units to make the loss predictable.

As one of the means to effectively manage the risk process, insurance had been suggested in a number of studies as not only a scientific instrument of risk transfer methodology but thus ensure economic and financial stability, serves as substitute for government security programs, facilitates trade and commerce, and guarantees mobilisation of savings, to mention a few (Aduloju \& Ajemunigbohun, 2017; 0ke, 2012; Oluoma, 2014; Yinusa \& Akinlo, 2013). However, the unique characteristics of insurance, as a service, is that it is bought at the present only for the future realization of its essence. Earlier work of Ikupolati (2008) as cited Nwankwo and Ajemunigbohun (2016) emphasised the inherent nature of insurance service to include intangibility, inseparability, variability and transferability. According to Rossi and Black (2001) as cited in Kwofie, Yormekpe, Mensah and Botchway (2018), the patronage for insurance is said to make provisions for sufficient protection concerning loss that reduces the probability of fiduciary crises whenever they occasioned. In a similar remark, earlier study of Cummins and Danzon (1997) as cited in Dionne and Harrington (2017) reiterated that the decision concerning insurance patronage not only evident in the current condition of the product but showcases future benefits that are achievable.

Every organisation works in a competing environment, and if such desires to survive with the current dynamism, it has to surmount so many challenges that can possibly hinder its performance. Organisational performance, from quite a number of studies, has been concurred to impart on organisation's success or failure (Bin-Nashwan, Abdullah, \& Obaid, 2017; Buuni, Yusuf, Kilru, \& Kareem, 2015; Durendez, Rulz-Palomo, Garcia-Perez-de-Lema, \& Dieuez-soto, 2016). Organisational performance, according to Henri (2004) as cited in Rehman, Mohamed, \& Ayoup (2019), means the efficaciousness of an organisation in the attainment of its desired objectives. It is also seen as a determinant that measures how well an organisation achieve its goal (Zehir, Yildiz, Kole, \& Basar, 2016). Accordingly, Cokins (2004) as cited in Obalola and Ajemunigbohun (2017) remarked that managing performance helps managers to sense unforeseen situations at the earlier stage and give it a swift response. Earlier submission by Armstrong (2006) opined that managing organisation's performance assists in creating a high-performance culture whereby every organisation's member takes cognisance of frequently upward movement of the expertise and business activities. Vichitdhanadadee, Wilmshurst and Cliff (2009) stipulated that the survival and success of SMEs activities dependent upon the constant development of their performance alongside maintaining adequate resources encompassing employee and prompt information, combine them towards creating great deal of business benefits.

\section{Research methods}

In attainment of the objectives of this study, a descriptive survey design was adopted. The desire for the adoption of this design was because it involves the gathering of data from a number of cases; and thus, observed happenings around sample variables with no intent of manipulation and control over them. It also 
provides framework for quantitative or numeric description of trends, attitudes or opinions of a population by studying a sample of that population (Creswell \& Creswell, 2018; Wilson, 2014). Apart from having the potential ability to predict individual behaviours, it thus helps in information gathering which are the same concerning all sample subjects (Sekaran \& Bougie, 2016). Data gathering was effected via the field work among selected small and medium-sized enterprises whose businesses cut across trade, education, food processing, retail services, manufacturing, and other services. With the assistance of a questionnaire. The desire for choosing the respondents were because of their crucial purpose to the economic sustenance of our nation. The use of the data gathering instrument was due to its suitability to the design of the research with regards to being relatively inexpensive, wider and more distribution of sample representation, sufficiency of time for respondents to allocate well thought out responses and simplicity in administering the instrument (Kothari \& Garg, 2016).

In accordance with the Small and Medium Enterprises Development Agency of Nigeria (2013), the totality of micro, small and medium enterprises (MSMEs) as cited in Peter, Adegbuyi, Olokundun, Peter, Amaihian, and Ibinunmi (2018) stood at 37,067,416 with 36, 914,578 micro, 68,168 small and 4,670 medium enterprises. The Lagos State, the research ground, is said to have a share of 11,666 registered SMEs. 10 local government council areas out of the 20 acknowledged and approved local government councils were exerted as research study areas with the adoption of single-stage cluster sampling technique. The purpose for choosing this sampling method was because it permitted researchers to split the population into convenient clusters by randomly selecting the needed number of clusters as sample variables and examined all the subjects in each of the randomly selected clusters. This sampling technique is advantageous because it saves time and money (Wilson, 2014). The entire sample size for the study was statistically determined by Yamane's (1967) formula as cited by Ajay and Masuku (2014) as follows:

$$
\begin{gathered}
n=\frac{N}{1+N e^{2}} \\
n=\frac{11,633}{1+11,633(0,05)^{2}}=386
\end{gathered}
$$

where:

$\mathrm{n} \quad=$ the sample size,

$\mathrm{N}=\quad=$ the population size,

e $\quad=$ the acceptable sampling error

$95 \%$ confidence level and $\mathrm{p}=0.05$ are assumed

In assessing the above calculated sample size, the researchers pondered this number to be an impressive representation of the total population under study. Data gathering period was between September, 2019 to December, 2019. Most importantly, 256 copies out of the 386 copies of questionnaire distributed among selected SMEs operators/owners were found useful for analysis of the research results; providing $66 \%$ response rate. In order to process collected data successfully, the Kolmogorov-Smirnov test and Simple regression techniques were employed. Accordingly, five Likert scaling measurements of "agree", "indifferent", and "disagree" were adopted.

In a bid to achieve the intent behind the choice of data collection instruments, a pilot study test was conducted for measures of reliability and validity. The pilot test result produced Cronbach alpha of 0.7613 overall, showcasing an upscale beyond the 0.7 standard. The study took account of the validity with the observation of content and congruent validity. While the former involved the distribution of chosen research instrument to few selected SMEs operators/owners and some few academic members of staff in the field of business, entrepreneurship, risk management and insurance for expert opinions, the latter took evaluation of selected variables conceptually from past literature.

\section{Results and discussion Hypothesis one}

SMEs operators' risk attitudes have no significant influence on their market share in the Lagos metropolis. Table 2 underneath showcases a result of the calculated D value of the point of the greatest difference between the cumulative distributions and cumulative observations, which stands at $(0.085)$. the estimated $\mathrm{D}$ value through the Kolmogorov-Smirnov test techniques is given as:

$$
/ F_{0}(X)-F_{r}(X) /
$$

where:

$\mathrm{F}_{\mathrm{o}}(\mathrm{X})$ observed cumulative frequency distribution of a random sample $\mathrm{n}$ observation,

$\mathrm{F}_{\mathrm{r}}(\mathrm{X}) \quad \mathrm{k} / \mathrm{n}=$ (number of observations $\left.\leq \mathrm{X}\right) /$ (Total number of observations),

$F_{i}(X)$ the theoretical frequency distribution. 
The critical value of D is established from the K-S table values for one sample test or determined as below:

$$
\mathrm{D}=\frac{\alpha}{\sqrt{\mathrm{N}}}=\frac{1,36}{\sqrt{256}}=0,085
$$

where:

D calculated value

$\alpha \quad$ alpha

$\mathrm{N}$ population size

Acceptance Criteria: If the calculated value is less than critical value accepts null hypothesis.

Rejection Criteria: If calculated value is greater than table value rejects null hypothesis

Table 1. Responses to the testing of hypothesis 1

\begin{tabular}{clc} 
Scaling measurements & Responses & Percentage (\%) \\
\hline Agree & 54 & 21.1 \\
Indifferent & 49 & 19.1 \\
Not Agree & 153 & 59.8 \\
Total & 256 & 100 \\
\hline \multicolumn{2}{c}{ Source: Authors' Field work, $n=256$}
\end{tabular}

Table 2. Kolmogorov-Smirnov Frequency Table for Hypothesis 1

\begin{tabular}{lccc} 
Hypothesis & Agree & Indifferent & Not agree \\
\hline $\begin{array}{l}\text { F = SMEs operators' risk attitudes have no significant influence } \\
\quad \text { On their market share in Lagos metropolis }\end{array}$ & 49 & 153 \\
$\mathrm{~F}_{0}(\mathrm{X})$ = Theoretical cumulative distribution of choice & 0.3333 & 0.6666 & 1 \\
$\quad$ Under Ho & & \\
$\mathrm{F}_{\mathrm{i}}(\mathrm{X})=$ Cumulative distribution of observed choices & 0.2109 & 0.4023 & 1 \\
$\left|\mathrm{~F}_{\mathrm{o}}(\mathrm{X})-\mathrm{F}_{\mathrm{i}}(\mathrm{X})\right|$ & 0.1224 & 0.2643 & 0 \\
\hline
\end{tabular}

Source: Authors' computation, 2019

With the submission above, it is crystal clear that the estimated/calculated D value $(0.2643)$ is greater than the critical value of 0.085 , indicating that the null hypothesis (Ho) that SMEs operators' risk attitudes have no influence on their market share in Lagos metropolis is rejected at $\alpha=0.05$ (see table 2). This therefore implies that the alternative hypothesis that SMEs operators' risk attitudes have significant influence on their market in Lagos metropolis is accepted in reference with the participants' responses. This result is consistently supported by recent study of Afolabi and James (2018), who noted that SMEs risk attitudes have influential effects on their risk management practices. The research findings corroborated other recent studies such as Akguc, Liu, Tani and Zimmermann (2016); Johnson, Soderberg and Wilhelmsson (2017); Zawojska, Bartczak, and Czajkowski (2019); to mention few. In support of the subsisting research findings, Ledwin and Watson (2019) mentioned that the incorporation of the entrepreneur's risk attitude into the risk management plans adoption techniques of SMEs is essential to ensure durable solutions in terms of perceived probability of market occurrence, perceived probability of its impact and perceived severity of its impact. There are also divergent views from other numerous studies (such as Lundahl \& Silver, 2008; Rad, Yazdanfar \& Ohman, 2014) who established that customer satisfaction is a key driver from the level of risk attitude displayed in the pursuit of financial attainment. They further noted that there is significant relationship between risk attitude and customer satisfaction of SMEs.

\section{Hypothesis 2}

In an attempt to confirm the significant relationship between insurance patronage and financial earnings of SMEs operators in Lagos metropolis, the simple linear regression technique is adopted for analytical examination. This statistical approach establishes a relationship between dependent variable (y) and one or more independent variables (X) using a best fit straight line (thus known as regression line). It is also represented by an equation $\mathrm{Y}=\mathrm{a}+\mathrm{bX}+\mathrm{e}$, where $\mathrm{a}$ is intercept, $\mathrm{b}$ is slope of the line and e is error term. The regression model implies the class of stochastic models represented by an equation where a dependent variable is expressed as a linear or nonlinear function of independent variables (Rusov, Misita, Milanovic \& Milanovic, 2017; Saracli, Yilmaz \& Dogan, 2009). 
With regards to test of hypothesis, table model summary shows the results of a linear regression analysis of insurance patronage as a predictor of financial earnings. The R-squared statistic as explained by the fitted model implies that about $8.9 \% \%$ of the total variation in the measurement of financial earnings is explained by the variations in insurance patronage. The ANOVA results for insurance patronage as a predictor of financial earnings is statistically significant with $F(24.871), p<0.01$. The regression coefficient, $t$ statistic and $p$ value for the model shows that insurance patronage $(\beta=0.135, t=4.952, p<0.05)$ implies a low but statistically significant effect on financial earnings. Therefore, the hypothesis can be rejected, and hence it can be concluded that SMEs operators' patronage of insurance will have significant relationship on their financial earnings. The result corroborates the submission of Ajemunigbohun and Adeoye (2018), who established a positive but low relationship between insurance awareness and acceptance among small and medium-sized enterprise in the metropolis of Lagos. The study of Amoako (2019) noted that the inexperience of SMEs risk management and negative insurance perception had impinged upon their risk acceptance attitude which affect their financial earnings. In consistent with the existing results, Osho and Ademuyiwa (2017) demonstrated in their study of the low level of insurance patronage by entrepreneurs which in turn imparted on the entrepreneurship development in Nigeria.

\begin{tabular}{|l|r|r|r|r|}
\hline & Model Summary \\
\hline Model & $\mathrm{R}$ & \multicolumn{1}{|c|}{ R Square } & Adjusted R Square & Std. Error of the Estimate \\
\hline 1 & $.299 \mathrm{a}$ & .089 & .086 & 1.97447 \\
\hline
\end{tabular}

a. Predictors: (Constant), SMEs' insurance patronage

\begin{tabular}{|ll|r|r|r|r|r|}
\hline Model & & Sum of Squares & Df & Mean Square & \multicolumn{1}{c|}{ F } & Sig. \\
\hline 1 & Regression & 95.586 & 1 & 95.586 & 24.518 & $.000^{\mathrm{b}}$ \\
& Residual & 974.636 & 254 & 3.899 & & \\
& Total & 1070.222 & 255 & & & \\
\end{tabular}

a. Dependent Variable: financial earnings

b. Predictors: (Constant), SMEs' insurance patronage

\begin{tabular}{|c|c|c|c|c|c|c|}
\hline \multicolumn{7}{|c|}{ Coefficients $^{\mathbf{a}}$} \\
\hline \multirow{2}{*}{\multicolumn{2}{|c|}{ Model }} & \multicolumn{2}{|c|}{$\begin{array}{c}\text { Unstandardized } \\
\text { Coefficients }\end{array}$} & $\begin{array}{c}\text { Standardized } \\
\text { Coefficients }\end{array}$ & & \\
\hline & & $\mathrm{B}$ & Std. Error & Beta & $\mathrm{t}$ & Sig. \\
\hline \multirow[t]{2}{*}{1} & (Constant) & 5.808 & .569 & & 10.215 & .000 \\
\hline & SMEs' insurance patronage & .135 & .027 & .299 & 4.952 & .000 \\
\hline
\end{tabular}

a. Dependent Variable: financial earnings

\section{Conclusion, Recommendations and Future studies}

This study attempted to ascertain the relationship between risk attitude, insurance patronage and small and medium enterprises' performance in the metropolis of Lagos. The results of the study have clearly shown significant influence of risk attitudes on the market share of SMEs within the Lagos metropolis. The study thus gave an empirical evidence which indicated a significant but low relationship between SMEs' insurance patronage and their financial earnings in Lagos metropolis. Importantly, convincing SMEs operator/owners as to the realisation of their individual risk attitude, insurance patronage and their performance (in terms of customer relationship and financial earnings) is decisive plan to combating the challenges of low popularity and patronage of insurance products and poor risk measurement template to improve sales. Therefore, accepting insurance as a scientific technique to handling the various risks which they may be confronted with, ranging from fire risks, health risks, business interruption risks, income risks, theft risks, etc., would help SMEs operators' optimally in their risk management practices.

As recommendations of the study, risk management strategies should be designed as promptly as possible to help sensitise business, management and entrepreneurial students and operators in order to contain the subsisting recessionary economic downturn in Nigeria. Insurance practitioners should thus ensure that they design tailor-made products that would entice SMEs operators as a financial machinery to 
control possible risks. The SMEs operators should endeavour to shift their responsibilities of managing and handling the burden of risk off to the insurance companies for sufficient business, economic and financial safety. Stakeholders such as government, insurance practitioners, academics and business tycoons should collaborate and integrate their knowledge, regulatory and financial based resources to help incorporate, implement and fund insurance education curriculum that will facilitate progress, steady growth and development of the youths. Lastly, greater focus should be placed on SMEs' sound risk management communication and proper risk financing method like insurance.

The research suggests that further focus on insurance acceptance among small and medium-sized enterprises. They should also look at socio-cultural, demographic and economic factors that will influence insurance consumption among small and medium scale enterprises. They should endeavour to carry out an analytical study of the possible risk management template that would possibly work for small and mediums scale enterprises in the metropolis of Lagos.

\section{References}

1. Abotsi, A., Dake, G., \& Ayyepong, R. (2014). Factors influencing risk management decision of small and medium scale enterprise in Ghana. Ghana: Vizja Press \& IT.

2. Adamu, I.Y. (2018). Acceptance and patronage of insurance services in Northern Nigeria. IOSR Journal of Humanities and Social Science, 23 (4), 32-43

3. Adeleke, I., Olowokudejo, F., \& Ajemunigbohun, S. (2016). Hazard perception and demand for insurance among selected motorcyclists in Lagos, Nigeria. The South East Asian Journal of Management, 10 (2), 121-140.

4. Aduloju, S.A., \& Ajemunigbohun, S.S. (2017). Reinsurance and performance of the ceding companies: The Nigerian insurance industry experience. Economics and Business, 31 (1), 19-29.

5. Aduloju, S.A., Isimoya, O.A., \& Ajemunigbohun, S.S. (2018). Socio-economic factors and demand for fire insurance in residential properties: Evidence from selected homeowners in Lagos metropolis, Nigeria. LASU Journal of Business Review, 5 (1), 179-190

6. Afolabi, T.S., \& James, J.T. (2018). Risk management and performance of small and medium enterprise in Osun State, Nigeria. Archives of Business Research, 6 (12), 157-163

7. Ahmed, A., \& Zalina, S. (2008). An assessment on service quality in Malaysia insurance industry. Communication of the IBIMA, 1 , 13-26.

8. Ajay, S., \& Masuku, M.B. (2014). Sampling techniques and determination of sample size in applied statistics research: An overview. International Journal of Economics, Commerce and Management, 2 (1), 1-22.

9. Ajemunigbohun, S.S., \& Adeoye, A.O. (2018). Insurance awareness and awareness: Empirical evidence among small and mediumsized enterprises in Lagos state, Nigeria. Trend Economics and Management, 32 (2), 9-20.

10. Ajemunigbohun, S.S., \& Oreshile, A.S. (2014). Risk attitude and demand for motor insurance: An examination of selected motorists in Lagos State, Nigeria. Journal of Developing Country Studies, 2 (21), 114-152.

11. Akguc, M., Liu, X., Tani, M., \& Zimmermann, K.F. (2016). Risk attitude and migration. China Economic Review, 37, 166-176

12. Amoako, E.O. (2019). Patronage of non-life insurance policies: The case of SMEs in Kumasi metropolis. Applied Mathematics, 9 (3), 67-81

13. Armstrong, M. (2006). Key strategies and practical guidelines. $3^{\text {rd }}$ ed. London: Kogan.

14. Ayyagari, M., Demirguc-Kunt, A., \& Maksimovic, V. (2011). Small vs. young firm across the World: Contribution to employment, job creation and growth. Policy Research. Working Paper, 5631, World Bank: Washington, DC.

15. Badru, F.A., Yusuf, T.O., \& Isola, W. (2013). Socio-cultural factors affecting insurance patronage in Laos State, Nigeria: An exploratory study. Hemispheres, 28, 5-19

16. Bin-Nashwan, S.A., Abdullah, N.S., \& Obaid, M.M. (2017). A review of literature in management control system (MCS) business strategy, and firm's performance. International Journal of Management Research and Review, 7 (2), 99-112.

17. Buuni, H., Yusuf, A., Kilru, G., \& Karemu, G. (2015). Strategic plan implementation and organisational performance: A case of Hargeisa water agency in Somaliland. IOSR Journal of Business and Management, 17, 60-66.

18. Charles, R.M., \& Kioku, U.M. (2016). Effect of health insurance on demand for outpatient medical care in Rwanda: An application of control function approach. Rwanda Journal Series B: Social Sciences, 3, 77-100

19. Chatterjee, A., \& Wehrhahn, R. (2017). Insurance for micro, small and medium-sized enterprise. No. 78. ADR Brief.

20. Chitiyo, F.E. (2017). Demand for non-life insurance: Evidence from selected insurance markets in Africa. Master Dissertation of the Development Finance Centre, Graduate School of Business, University of Cape Town.

21. Chodokufa, K. (2009). An analysis of the business relationship between SMEs and insurance companies in the Nelson Mandela metropolitan area. Dissertation submitted for Master programme, Faculty of Management and Commerce, University of Fort Hare, South Africa.

22. Collier, P.M. (2009). Fundamentals of risk management for accountants and managers. UK: Butterwork-Heinemann Publication.

23. Creswell, J.W., \& Creswell, J.D. (2018). Research design: Qualitative, quantitative and mixed method approaches. $5^{\text {th }}$ ed. California: Sage Publication Incorporation.

24. Dafikpaku, E. (2011). The strategic implications of enterprise risk management: A framework. ERM Symposium.

25. Dionne, G. \& Harrington, S.E. (2017). Insurance and insurance markets. Interuniversity Research entre on Enterprise Networks, Logistics and Transportation, Canada.

26. Dougherty-Choux, L., Terpstra, P., Kammila, S., \& Kurukulasuriya, P. (2015). Adapting from the ground up: Enabling small businesses in developing countries to adapt to climate change. World Resources Institute and United Nations Development Programme, Washington, $D C$.

27. Durendes, A., Rule-Palomo, D., Garcia-Perez-de-Lema, D., \& Diegnez-Soto, J. (2016). Management control system and performance in small and medium family firms. European Journal of Family Business, 6 (1), 10-20.

28. Eregue, P.E. (2017). Basic insurance for schools and colleges. Lagos: Mbeyi \& Associates (Nigeria) Limited.

29. Fadun, O.S. (2013). Risk management and risk management failure: Lessons for business enterprises. International Journal of Academic Research in Business and Social Sciences, 3 (2), 225-239.

30. Fatemi, A., \& Glaum, M. (2000). Risk management practices of German firms. Journal of Management Finance, 26 (3), 1-17

31. Fofie, G.A. (2016). What influence customer patronage of insurance policies: An empirical assessment of socio-economic and demographic determinants of insurance patronage in Ghana. International Review of Management and Marketing, 6 (1), 81-88.

32. Garg, A., \& Makukule, P. (2015). Business risk management - The key success factors: Evidence from Shebeens and taverns in Soshanguve Township. Problems and Perspective in Management, 13 (2), 71-81. 
33. Gatzert, N., \& Martin, M. (2013). Determinants and value of enterprise risk management: Empirical evidence from the literature. Working Paper, Friedrich-Alexander University (FAU), Erlangen-Numberg

34. Glanz, B.I., Greeke, E., LaRussa, A., Stuart, F., Rintell, D.J., Chitnis, T., \& Healy, B.C. (2016). Risk attitudes and risk perceptions in individual with multiple sclerosis. Multiple Sclerosis Journal-Experimental, Translational and Clinical, 2, 1-11.

35. Hill, R. (2000). Human resource development in mall organization. Journal of European Industrial Training, 24 (2/3/4), 105-117.

36. Insurance Information Institute (2005). Spreading awareness of insurance to small business. ADB Brief, September.

37. Janney, T., \& Dess, G. (2006). The concept for entrepreneurs considered new challenges to the conventional wisdom. Journal of Business Venturing, 21 (3), 385-400.

38. Johnson, S., Soderberg, I.L., \& Wilhelmsson, M. (2017). An investigation of the impact of financial literacy, risk attitude, and saving motives on the attenuation of mutual fund investors' disposition bias. Management Finance, 43 (3), 282-298.

39. Kleffner, A.E., Lee, R.B., \& McGannon, B. (2003). The effect of corporate governance on the use of enterprise risk management: Evidence from Canada. Risk Management and Insurance Review, 6, 53-73.

40. Kothari, C., \& Garg, G. (2016). Research methodology: Methods and techniques. $3^{\text {rd }}$ ed. New Delhi: New Age International (P) Limited.

41. Kwofie, C., Yormekpe, D.D., Mensah, S.D., \& Botchway, P. (2018). Choosing between alternative motor insurance policies: A discrete choice experiments. Hindawi International Journal of Mathematics and Mathematical Sciences, 1-6

42. Labadova, A. (2004). Implementing integrated management systems using risk analysis-based approach. Journal of Cleaner Production, 12, 571-580.

43. Langat, W.K., Naibei, I., \& Getare, C.M. (2017). Determinants of insurance uptake on developing countries: Evidence from CIC insurance Kericho branch, Kenya. International Journal of Scientific and Research Publications, 7 (2), $703-715$.

44. Ledwin, C., \& Watson, M. (2019). Risk attitude, risk perception and risk management strategies adoption in Zimbabwean small and medium enterprises. Journal of Management and Economic Studies, 1 (2), 53-68.

45. Lundahl, N., \& Silver, L. (2008). In pursuit of key drivers of customer satisfaction in the SME-Bank relationship. The Royal Institute of Technology. Sweden

46. Mambula, C. (2002). Perception of SMEs growth constraints in Nigeria. Journal of Small Business Management, 40 (1), $58-65$.

47. Neneh, N., \& Van Zyl, J. (2012). Achieving optimal business performance through business practices: Evidence from SMEs in selected areas in South Africa. Southern African Business Review, 16 (3), 118-144.

48. Nwankwo, S.I., \& Ajemunigbohun, S.S. (2013). Customer relationship management and customer retention: Empirical assessment from Nigeria's insurance industry. Business and Economic Journal, 4 (081), 1-6.

49. Nwankwo, S.I., \& Ajemunigbohun, S.S. (2016). Empirical examination of electronic payment systems in service delivery of insurance companies in Nigeria. Journal of Economics and Management, 24 (2), 64-76

50. Nyce, C.M. (2007). Foundations of risk management and insurance. $2^{\text {nd }}$ ed. Pennsylvania: American Institute for Chartered Property Casualty.

51. Obalola, M.A., \& Ajemunigbohun, S.S. (2017). An analytical study of business risk management among selected small and medium enterprises in Laos State, Nigeria. LASU Journal of Business Review, 4 (1), 35-46.

52. Ojikutu, R.K., Yusuf, T.O., \& Oblola, M.A. (2011). Attitude and perception about insurance fraud in Lagos State, Nigeria. European Journal of Scientific Research, 57 (4), 615-625.

53. Oke, 0. (2012). Insurance sector development and economic growth in Nigeria. African Journal of Business Management, 6 (23), 7016-7023.

54. Okechukwu, C.S. (2016). The bane of selling general insurance in Nigeria. International Journal for Social Studies, 2 (3), $130-149$.

55. Olowokudejo, F.F., \& Ajemunigbohun, S.S. (2018). The nexus of claims settlement process and customer retention: Evidence from the Nigerian Insurance Industry. Ijagun Journal of Social and Management Science, 5 (2), 84-100.

56. Olsson, C. (2002). Risk management in emerging markets: How to survive and prosper. Great Britain: Pearson Education Limited.

57. Oluoma, R.O. (2014). Impact of insurance market activity on economic growth in Nigeria. Ph.D. thesis, University of Nigeria, Nsukka, Nigeria.

58. Osho, L.A., \& Ademuyiwa, M.A. (2017). Insurance and entrepreneurship development: Focus on Nigeria. International Journal of Entrepreneurial Development, Education and Science Research, 4 (1), 46-57.

59. Outreville, F. (1998). Theory and practice of insurance. New York: Springer Science+Business Media.

60. Ow, P. (2007). Embedding risk management practices for improved organisational performance. Available at :http://www./fac.org/sites/default/files/publications/files/embedding-risk management-.p.pdf

61. Owolabi, A.O., \& Agboola, O.O. (2018). Insurance purchase: Price, product, promotion, and consumers attitude perspective. Business and Management Horizons, 6 (1), 44-58.

62. Peter, F.O., Adegbuyi, O., Olokundun, M.A., Peter, A.O., Amaihian, A.B., \& Ibidunmi, S.A. (2018). Government support and financial performance of SMEs. Academy of Strategic Management Journal, 17 (3), 1-10.

63. Rad, A., Yazdanfar, D., \& Ohman, P. (2014). Female and male risk aversion: An empirical study of loan officers' assessment of SMEs loan applications. International Journal of Gender and Entrepreneurship, 6 (2), 121-141

64. Redja, G., \& McNamara, M. (2014). Principles of risk management and insurance. $12^{\text {th }}$ ed. USA: Pearson Education, Inc.

65. Rehman, S., Mohamed, R. \& Ayoup, H. (2019). The mediating role of organisational capabilities between organisational performance and its determinants. Journal of Global Entrepreneurship Research, 9 (30), 1-23

66. Ruchkina, G., Melnichuk, M., Frumina, S., \& Mentel, G. (2017). Small and medium enterprises in the context of regional development and innovations. Journal of International Studies, 10 (4), 259-271.

67. Rusov, J., Misita, M., Milanovic, D.D., \& Milanovic, D.L. (2017). Applying regression models to predict business results. Faculty of Mechanical Engineering Journal, 45 (1), 198-202.

68. Saeidi, P., Sofian, S., Abdul Rasid, S.Z., Saeidi, S.P., \& Saeidi, S.P. (2013). The role of trust in enterprise risk management. International Journal of Business and Behavioural Science, 3 (2), 17-25.

69. Saracli, S., Yilmaz, V., \& Dogan, I. (2009). Simple linear regression techniques in measurement errors models. Anadolu University Journal of Science and Technology, 10 (2), 335-342

70. Sekaran, U., \& Bougie, R. (2016). Research methods for business: A skill building approach. $7^{\text {th }}$ ed. USA: John Wiley \& Sons Limited.

71. Sulaiman, L.A., Migiro, S., \& Yeshihareg, T. (2015). Investigating the factors influencing the life insurance market in Ethiopia. Problems and Perspectives in Management, 13 (2), 152-160.

72. Turpin, M. (2002). Risk management in Europe: An investigation of medium-sized enterprise. London: Marsh \& McLennan Companies.

73. Vaughan, E.J., \& Vaughan, T.M. (2014). Fundamental of risk and insurance. $11^{\text {th }}$ ed. USA: John Wiley \& Sons, Inc

74. Vichitdhanabadee, J., Wilmshurst, T., \& Cliff, R. (2009). Performance management practical in the Thai SMEs. Available at: http//www.pma.otao.ac.nz/pma-ac/papers/1027.pdf.

75. Wilson, J. (2014). Essential of business research: A guide to doing your research project. $2^{\text {nd }}$ ed.London: Sage Publication Limited. 
76. Wu, W., \& Chaug, M. (2007). The role of risk attitude on online shopping: Experience, customer satisfaction, and repurchase intention. Social Behaviour and Personality, 35 (4), 453-468.

77. Yazid, A., Razadi, A., \& Hussin, M. (2012). Determinants of enterprise risk management (ERM): A proposed framework for Malaysian public listed companies. International Business Research, 5 (1), 80-86.

78. Yinusa, O., \& Akinlo, J. (2013). Insurance development and economic growth in Nigeria, 1986-2010. Journal of Economics and International Finance, 5 (5), 218-224.

79. Zawojska, E., Bartczak, A., \& Czajkowski, M. (2019). Disentangling the effects of policy and payment consequentiality and risk attitude on stated preferences. Journal of Environmental Economics and Management, 93, 63-84

80. Zehir, C., Yildiz, H., Kole, M., \& Basar, D. (2016). Superior organizational performance through SHRM implications, mediating effect of management capability: An implementation on Islamic banking. Procedia-Social and Behavioural Sciences, 235, 807-816. 